\title{
Zeolite Synthesis under Insertion of Silica Rich Filtration Residues from Industrial Wastewater Reconditioning
}

\author{
Andrea Hartmann ${ }^{*}$, V. Petrov' ${ }^{1}$ J.-C. Buhl ${ }^{1}$, K. Rübner ${ }^{2}$, \\ M. Lindemann², C. Prinz ${ }^{3}$, A. Zimathies ${ }^{3}$ \\ ${ }^{1}$ Institut für Mineralogie, Universität Hannover, Hannover, Germany \\ ${ }^{2}$ Fachgruppe VII.1 Baustoffe, Bundesanstalt für Materialforschung und -prüfung (BAM), Berlin, Germany \\ ${ }^{3}$ Fachbereich 1.3 Strukturanalytik Richard-Willstätter, Bundesanstalt für Materialforschung und -prüfung (BAM), \\ Berlin, Germany \\ Email: *a.hartmann@mineralogie.uni-hannover.de
}

Received 22 February 2014; revised 22 March 2014; accepted 29 March 2014

Copyright (C) 2014 by authors and Scientific Research Publishing Inc.

This work is licensed under the Creative Commons Attribution International License (CC BY). http://creativecommons.org/licenses/by/4.0/

c) (i) Open Access

\section{Abstract}

Zeolite synthesis was studied using two silica rich filtration residues (FR 1 and FR 2) as Si-source and sodium aluminate in a direct synthesis at $60^{\circ} \mathrm{C}$ at strong alkaline conditions ( $\left.8 \mathrm{M}-16 \mathrm{M} \mathrm{NaOH}\right)$. In addition to these one-pot syntheses, a two-step process was investigated. Here, an alkaline digestion of FR at $60^{\circ} \mathrm{C}$ was followed by gel precipitation with sodium aluminate and gel crystallization under usual conditions of $80^{\circ} \mathrm{C}-90^{\circ} \mathrm{C}$. The results show that the substitution of chemical reagent sodium silicate by a waste material like $\mathrm{FR}$ as $\mathrm{Si}$-source is possible but requires fine tuning of the reaction conditions as zeolite crystallization is a process under kinetic control. The solubility behaviour and impurities of the inserted filtration residues strongly influenced the course of reaction. Thus zeolites like hydrosodalite or intermediate zeolite between cancrinite and sodalite, or zeolite $\mathrm{NaA}$ or Z-21 in cocrystallization with hydrosodalite could be observed in the one pot syntheses already in a short time interval between $1-4 \mathrm{~h}$ depending on the alkalinity. The two step process yield to zeolites $\mathrm{NaA}$ and $\mathrm{NaX}$ in very good quality. The reaction process of FR in both reaction methods was characterized by chemical analyses, $X$-ray powder diffraction, Fourier transform infrared spectroscopy as well as scanning electron microscopy. Surface area and water content of selected products were further characterized by the BET-method and by thermogravimetry. Summing up the results, we can show that zeolite formation from filtration residues is possible by several reaction procedures as model cases for a re-use of industrial waste materials. Beside the importance for environmental protection, the reactions are of interest for zeolite chemistry as the re-use of FR is possible under economically conditions of low energy consumption at $60^{\circ} \mathrm{C}$ and short reaction periods.

\footnotetext{
Corresponding author.
} 


\section{Keywords}

\section{Zeolites, Superalkaline Conditions, Filtration Residues, Re-Use of Industrial Waste, Reaction Kinetics, Silica Residue}

\section{Introduction}

Zeolites are very important microporous materials, widely used in industry as sorbents, ion exchangers and catalysts. Most of the zeolites have aluminosilicate framework structures with different pore openings like the famous zeolites LTA and X. The outstanding zeolite LTA ("Linde Type A" structure) exhibits $4.1 \AA$ sized pores in its sodium form and is mainly inserted as water softener in detergents. The "Faujasite" structure type zeolite $\mathrm{Na}-\mathrm{X}$ successful used in catalysis has wider pores of $7.4 \AA$ [1]-[3]. Usually zeolites were synthesized from alkaline aluminosilicate gels obtained by mixing of sodium silicate and sodium aluminate solutions. The gels were crystallized under mild hydrothermal conditions around $80^{\circ} \mathrm{C}$ for several hours [2] [3].

The chemical composition of gels for syntheses of important aluminosilicate zeolites is settled in the systems $\mathrm{Na}_{2} \mathrm{O}-\mathrm{Al}_{2} \mathrm{O}_{3}-\mathrm{SiO}_{2}-\mathrm{H}_{2} \mathrm{O} ; \mathrm{K}_{2} \mathrm{O}-\mathrm{Al}_{2} \mathrm{O}_{3}-\mathrm{SiO}_{2}-\mathrm{H}_{2} \mathrm{O}$ and $\mathrm{CaO}-\mathrm{Al}_{2} \mathrm{O}_{3}-\mathrm{SiO}_{2}-\mathrm{H}_{2} \mathrm{O}$. Beside pure chemicals even many industrial waste materials are suitable educts for zeolite formation. Models of use of adequate industrial wastes in zeolite chemistry would be of interest for waste management and environmental protection as well as a cheaper production under the premise of insertion of waste materials.

Materials like fly ash or slag with high concentrations of silica, aluminum oxide as well as an alkali (Na, K) and/or alkaline earth (Ca) content were already inserted in zeolite crystallization [4]-[9]. Synthesis of zeolites from fly ash of composition $50 \%$ by mass $\mathrm{SiO}_{2}$ und $31 \%$ by mass $\mathrm{Al}_{2} \mathrm{O}_{3}$ and temperatures up to $250^{\circ} \mathrm{C}$ in 0.1 4.0 M NaOH, $0.1-4.0 \mathrm{M} \mathrm{KOH}$ and $0.1-1.0 \mathrm{M} \mathrm{NaCl}, \mathrm{KCl}$ und $\mathrm{CaCl}_{2}$ was investigated in [5]. Crystallization of analcite, Na-chabasite, K-chabasite, Faujasite and Phillipsit was observed under these conditions [5].

Zeolite LTA was successful synthesized from alumina rich slag in [10] by a more complex process. Starting with a melting step, followed by hydrothermal treatment to obtain sodium aluminum silicate as intermediate product finally crystallization was performed in $\mathrm{NaOH}$ solution for $1-9 \mathrm{~h}$ at $90^{\circ} \mathrm{C}$ [10].

As a contribution to investigate the applicability of further industrial waste materials beside slags or fly ash the present paper gives an experimental study on the insertion of filtration residues (FR) from waste water conditioning of production of silica, silane and zeolites. Those raw materials always exhibit high concentrations of $\mathrm{SiO}_{2}$ thus being proper educts for a re-use in zeolite production. The large amounts of those residues incurred in industries, mentioned above, were mostly only deposited up to day and our aim is to show possible ways of its conversion into zeolites as a model case for recovery of its valuable ingredients. The insertion of waste material for zeolite production is of interest for environmental protection as well as for zeolite chemistry to develop economically procedures by re-use of its own production residues. A substitution of chemical reagent sodium silicate as Si-source in zeolite industry by a waste material like FR is not as simple as one would expect because zeolite crystallization is a process under kinetic control. Phases beyond the thermodynamic equilibrium will result and the solubility behaviour of the educts or an insertion of structure directing agents is simply influencing nucleation and growth and thus the complete phase formation process [11]-[13]. Hence the synthesis results are more or less depending on the condition of the educts especially its composition, solubility behaviour and content of impurities.

Thus, the following principles of reaction were investigated in the present paper under substitution of chemical grade $\mathrm{Na}_{2} \mathrm{SiO}_{3}$ by filtration residues of different composition (FR 1 and FR 2). In a first series the possibility of direct formation of zeolites from FR in a so called "one pot synthesis" is studied at low temperature under strong alkaline conditions, first described in [14]-[16] for pure chemicals gels. The temperature of only $60^{\circ} \mathrm{C}$ and the simple "one pot" procedure would discharge this method in a very economically process under low energy consumption. As this synthesis requires superalkaline conditions, reactions under total $\mathrm{Na}_{2} \mathrm{O}: \mathrm{H}_{2} \mathrm{O}$ ratios equivalent to $8 \mathrm{M}, 12 \mathrm{M}$ and $16 \mathrm{M} \mathrm{NaOH}$ in the complete reaction batch are investigated. The conversion of the educts was studied in a short time interval between 1 - $4 \mathrm{~h}$ in dependence of the alkalinity. The results of this early period were compared with synthesis products obtained at a prolonged reaction time of $12 \mathrm{~h}$. Besides time dependent investigation of phase formation, an influence on crystal size and morphology was also found. 
In a second series, a two-step synthesis route is developed, starting with alkaline digestion of FR again at low temperature of only $60^{\circ} \mathrm{C}$ under $3 \mathrm{~h}$ digestion time. The digestion step was followed by common gel formation and crystallization under addition of $\mathrm{NaAlO}_{2}$ at temperatures of $353 \mathrm{~K}$ or $363 \mathrm{~K}$ and times up to $16 \mathrm{~h}$ as reveled in crystallization of industrial zeolite LTA and X [1]-[3].

The reaction process was characterized by chemical analyses using inductively coupled plasma optical emission spectrometry (ICP-OES) and by X-ray powder diffraction (XRD), Fourier transform infrared spectroscopy (FTIR) as well as scanning electron microscopy (SEM). Selected products were further characterized by the BET-method and by thermogravimetry.

The aims of this present experimental study are to investigate the mechanism and kinetics of zeolite formation as model case of a re-use procedure of filtration residue waste material (FR) by low energy consumption process at $60^{\circ} \mathrm{C}$ and short times. The study of conversion of FR in the early period of reaction and a control of phase stabilities at elevated times will further form the basis to clarify the question on occurrence of parallel- and follow up reactions in dependence of alkalinity and time at low reaction temperatures.

In addition, a characterization of the zeolite products from FR by BET-surface area and thermogravimetry in comparison with literature data will show if qualitative sufficient products can be expected from a re-use of the FR waste materials.

\section{Experimental}

\subsection{The Starting Raw Materials FR 1 and FR 2}

Chemical analysis of FR 1 and FR 2 was performed by inductively coupled plasma optical emission spectroscopy (ICP-OES) using an iCAP 6000 by Thermo Scientific. The powders were totally decomposed in an acid mixture (nitric acid, phosphoric acid, fluoroboric acid) by means of microwave digestion. The results of analyses of the main components are summarized in Table 1.

The amorphous character of the filtration residues was demonstrated by X-ray powder diffraction (XRD) of FR 1 and FR 2 (equipment and conditions of measurements see analytical methods below). The powder patterns of the raw materials are given in Figure 1. Few parts of crystalline quartz can be seen in the powder pattern of FR 2 according the slight but intense main reflections of $\mathrm{SiO}_{2}$ at $20.9^{\circ}, 26.6^{\circ}$ and $50.1^{\circ} 2 \theta$ in accordance with PDF46-1045 [17], whereas FR 1 is totally amorphous.

SEM investigations reveal the very fine grain size of both waste materials (see Figure 2, SEM results below). Nanoparticles around 100 - $200 \mathrm{~nm}$, agglomerated to bigger aggregates of $2 \mu \mathrm{m}$ and more were found for FR 1 and FR 2.

\subsection{The Experimental Routes: Direct One Pot Synthesis and Two Step Synthesis}

Direct syntheses with the filtration residues FR 1 and FR 2 were performed under magnetic stirring in $100 \mathrm{ml}$ beakers at $60^{\circ} \mathrm{C}$. Sodium aluminate (Riedel de Haen 13404) was added as an additive to depress the high $\mathrm{Si} / \mathrm{Al}$ ratio of the raw materials on values around 1.0 found in the technical important zeolites LTA and LSX (the low silica form ( $\mathrm{Si}: \mathrm{Al}=1$ ) of zeolite $\mathrm{X})$.

The amounts of $\mathrm{NaAlO}_{2}$ were therefore adapted to the individual $\mathrm{SiO}_{2}$ and $\mathrm{Al}_{2} \mathrm{O}_{3}$ contents of the filtration residues (see Table 1). Always $4 \mathrm{~g}$ FR and $\mathrm{NaAlO}_{2}$ amounts of $3.2 \mathrm{~g}$ (FR 1) or $4.8 \mathrm{~g}$ (FR 2) were mixed and 40 $\mathrm{ml} \mathrm{NaOH}$ (Fluka 71691) were added as mother liquor of synthesis. The resulting solid/liquid ratio of $0.1 \mathrm{~kg} / \mathrm{l}$ was selected to prevent production of higher amounts of waste aqueous $\mathrm{NaOH}$ solutions. In a first series the influence of the alkalinity was investigated by inserting $\mathrm{NaOH}$ solutions of high concentration, calculated according the total caustic ratio " $\mathrm{Na}_{2} \mathrm{O}: \mathrm{H}_{2} \mathrm{O}$ " equal to $8 \mathrm{M}, 12 \mathrm{M}$ and $16 \mathrm{M} \mathrm{NaOH}$. The main components within the

Table 1. Chemical composition of the filtration residues FR 1 and FR 2.

\begin{tabular}{|c|c|c|c|c|c|c|c|c|c|c|c|}
\hline \multicolumn{12}{|c|}{ Chemical composition (\% by mass) ${ }^{*}$} \\
\hline & $\mathrm{SiO}_{2}$ & $\mathrm{Al}_{2} \mathrm{O}_{3}$ & $\mathrm{Fe}_{2} \mathrm{O}_{3}$ & $\mathrm{TiO}_{2}$ & $\mathrm{CaO}$ & $\mathrm{MgO}$ & $\mathrm{Na}_{2} \mathrm{O}$ & $\mathrm{K}_{2} \mathrm{O}$ & $\mathrm{SO}_{3}$ & $\mathrm{Cl}^{-}$ & Loss of ignition \\
\hline FR1 & 80.50 & 2.32 & 1.30 & 0.12 & 0.85 & 4.25 & 4.60 & 0.74 & 4.84 & 0.45 & 14.62 \\
\hline FR2 & 92.3 & 3.83 & 0.49 & 0.05 & 2.05 & 0.19 & 0.01 & 0.05 & 0.23 & 3.23 & 3.23 \\
\hline
\end{tabular}

${ }^{*}$ free of loss of ignition. 


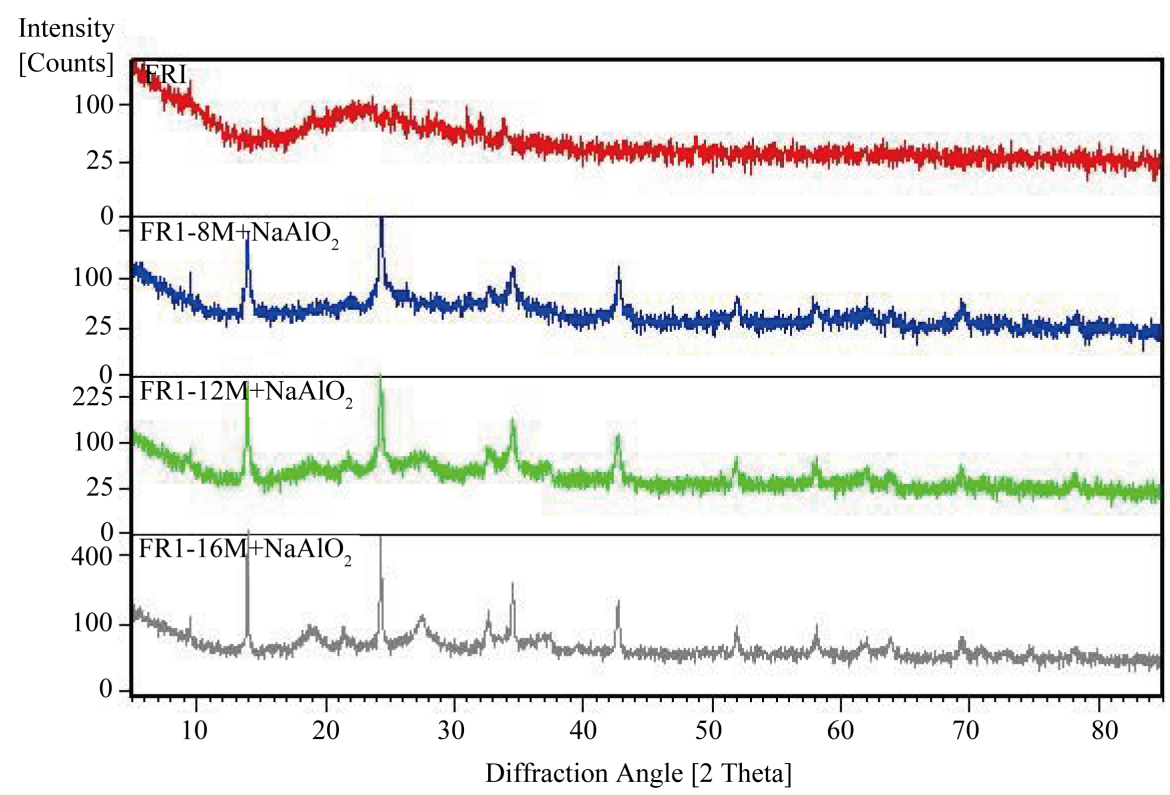

Figure 1. X-ray powder patterns of FR 1 and the products of FR $1+\mathrm{NaAlO}_{2}$ according to direct one pot synthesis at $60^{\circ} \mathrm{C}$ in dependence of the alkalinity.
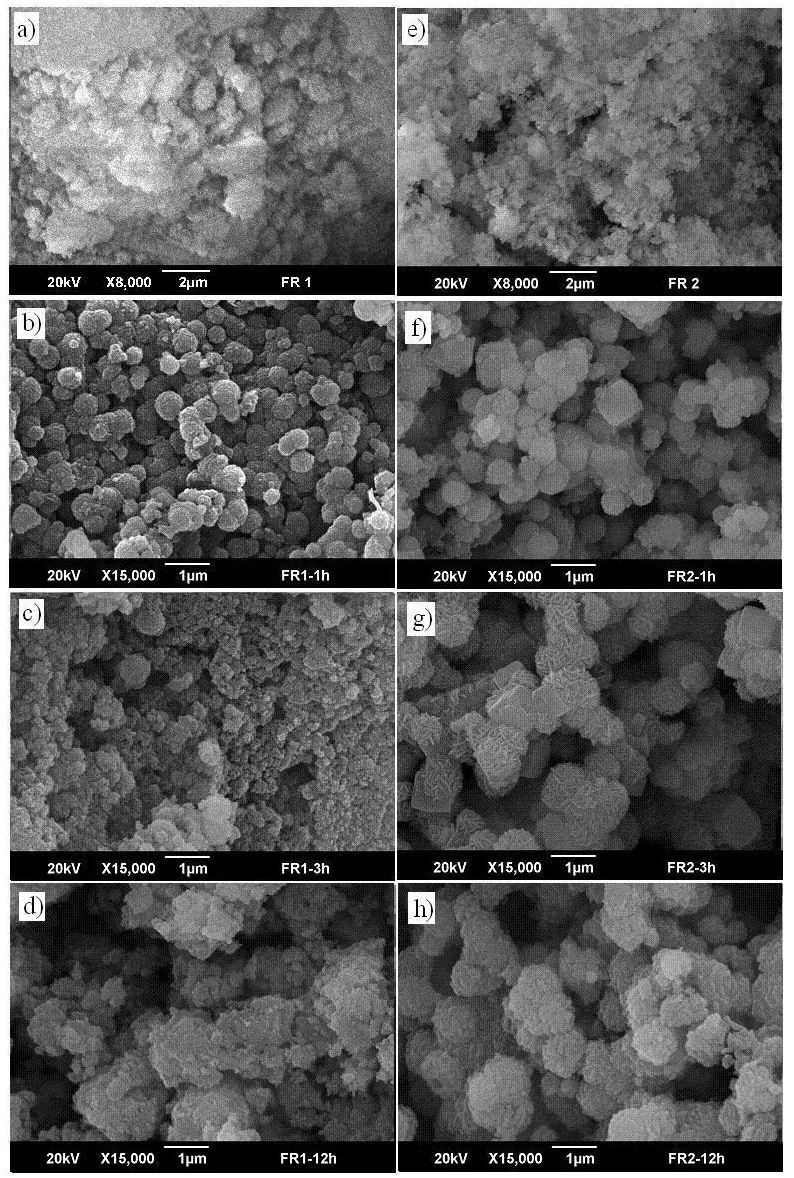

Figure 2. SEM images of the reaction products according to Table 3: left column: FR 1 raw material (a); FR 1-1h (b); FR 1-3h (c); FR 1-12h (d) and FR 2 right column: FR 2 raw material (e); FR 2-1h (f); FR 2-3h (g); FR 2-12h (h). 
solutions after the reactions were analysed by ICP-OES to develop possible ways for a reinsertion in zeolite formation process. A constant duration of $4 \mathrm{~h}$ was revealed for each experiment of the series on the influence of alkalinity.

Beside variation of alkalinity the one pot procedure was even performed to study the importance of the reaction time between 1 - $3 \mathrm{~h}$. An alkalinity of $8 \mathrm{M} \mathrm{NaOH}$ was therefore selected for both FR 1 and FR 2 on the basis of the results of the experiments under variation of the alkalinity. An additional sample with FR 1 as well as FR 2 was synthesized at a time of $12 \mathrm{~h}$ for comparison with result at the shorter reaction periods.

The whole experiences from one pot syntheses were then focused to develop a second synthesis pathway as alternative ways for production of pure phase zeolites A and X using FR 1 and FR 2. This "two step reaction route" started with an alkaline leaching of FR in $8 \mathrm{M} \mathrm{NaOH}$ at $60^{\circ} \mathrm{C}$ for $3 \mathrm{~h}$. After diluting the alkaline slurry with water and mixing with $\mathrm{NaAlO}_{2}$ gel crystallization was followed under usual conditions at $353-363 \mathrm{~K}$ for 3 - $16 \mathrm{~h}$ in steel autoclaves (see Table 2).

Independent from the reaction route all products were washed with $150 \mathrm{ml}$ water and dried at $80^{\circ} \mathrm{C}$ before characterization by diverse analytical methods.

\subsection{Analytical Methods}

Chemical analyses of selected reaction products (solid products and reaction solutions) were performed by inductively coupled plasma optical emission spectrometry (ICP-OES) as already described for the starting materials (chapter 2.1.).

The reaction process under variation of the alkalinity was followed gravimetrically too by weighting the solid products after each experiment on a Kern EMB 200-3 laboratory balance. Thus, first information on the digestion of the raw materials under the conditions of the different alkaline solutions were expected by evaluation of the mass of solids parallel to phase analysis by XRD as well as quantitative chemical analysis of the solutions after each experiment.

All reaction products were examined by X-ray powder diffraction (XRD) using a BRUKER D4 Endeavor powder diffractometer, with Bragg Brentano geometry and $\mathrm{Cu} \mathrm{K \alpha}$ radiation at $40 \mathrm{kV}$ and $40 \mathrm{~mA}$. 2668 steps of $0.03^{\circ}$ step wide were measured at $1 \mathrm{~s}$ measuring time per step in the 2 Theta range $5^{\circ}-85^{\circ}$. The winXpow software (Stoe \& Chi GmbH, Darmstadt) was revealed for data evaluation.

In addition to XRD FTIR spectroscopy was performed using a BRUKER IFS66v Fourier Transform IR spectrometer. $\mathrm{KBr}$ pellets were pressed with $200 \mathrm{mg} \mathrm{KBr}$ and $1 \mathrm{mg}$ of the sample. According to their IR- fingerprint [18] additional structural information on the zeolites were expected from the spectra. A simple detection of possible impurities from their typical vibration modes [19] like hydroxyl groups and carbonate anions, which are introduced within the products by the strong alkaline $\mathrm{NaOH}$ solution during the reactions, was a further aim of the FTIR investigation.

Crystal size and morphology of optimal products were characterized by scanning electron microscopy (SEM) on a JEOL JSM-6390A scanning electron microscope at an acceleration voltage of $20 \mathrm{kV}$, using Au-sputtered samples for optimal charge flow.

The water content of the products was measured by simultaneous thermal analysis on a Setaram Setsys Evolution t1750 thermoanalyzer. Samples were heated in an atmosphere of technical air $\left(80 \mathrm{ml} \mathrm{N} \mathrm{N}_{2}\right.$ and $20 \mathrm{ml} \mathrm{O}_{2}$, flow rate $20 \mathrm{ml} / \mathrm{min}$ ) up to $600^{\circ} \mathrm{C}$ at a rate of $5^{\circ} \mathrm{C} / \mathrm{min}$. After 30 min holding time at $600^{\circ} \mathrm{C}$ samples were cooled down to room temperature.

Additionally BET surface area of the zeolites was investigated by nitrogen sorption method at $77 \mathrm{~K}$ using a Micromeritics Accelerated Surface Area and Porosimetry System ASAP 2010.

\section{Results}

\subsection{Direct One Pot Synthesis at $60^{\circ} \mathrm{C}$ in Dependence of the Alkalinity}

The products of direct one pot synthesis, observed at $60^{\circ} \mathrm{C}$ in dependence of the alkalinity are given in Table 2 . Some additional experimental details and the mass ratio between solid products and solid educts as well as the insertion of $\mathrm{SiO}_{2}$ into the solid products are added to this table. The latter values were calculated according to the results calculated free of loss on ignition of chemical analysis, of solid FR 1 and 2 (Table 1) as well as analyses of the solutions, summarized in Table 3. Phase analysis was performed according to qualitative XRD analyses. The X-ray powder patterns of all these products are given in Figure 1, Figure 3. 
Table 2. Experimental conditions, syntheses products, mass ratio of solids (product/educts) and insertion of $\mathrm{SiO}_{2}$ into solid products of direct one pot syntheses in dependence of the alkalinity (temperature $60^{\circ} \mathrm{C}$, duration $4 \mathrm{~h}$ ).

\begin{tabular}{|c|c|c|c|c|c|c|}
\hline No & Sample & $\begin{array}{l}\mathrm{NaOH} \\
\mathrm{Mol} / \mathrm{l}^{*}\end{array}$ & $\mathrm{NaAlO}_{2}(\mathrm{~g})$ & Products* & $\begin{array}{c}\text { Mass ratio } \\
\text { product/educt }\end{array}$ & $\begin{array}{l}\mathrm{SiO}_{2} \text { in solid } \\
\text { product (\%) }\end{array}$ \\
\hline \multicolumn{7}{|c|}{ FR 1} \\
\hline 1 & $\mathrm{FR} 1-8 \mathrm{M}+\mathrm{NaAlO}_{2}$ & 8 & 3.2 & INT-1 + A & 0.85 & 66 \\
\hline 2 & FR1-12M+NaAlO & 12 & 3.2 & INT-2 + A & 0.78 & 57 \\
\hline 3 & $\mathrm{FR} 1-16 \mathrm{M}+\mathrm{NaAlO}_{2}$ & 16 & 3.2 & INT-2 + (A) & 0.80 & 53 \\
\hline \multicolumn{7}{|c|}{ FR 2} \\
\hline 4 & $\mathrm{FR} 2-8 \mathrm{M}+\mathrm{NaAlO}_{2}$ & 8 & 4.8 & $\mathrm{SOD}+(\mathrm{Z}-21)$ & 0.94 & 76 \\
\hline 5 & FR2-12M+NaAlO & 12 & 4.8 & $\mathrm{SOD}+\mathrm{Z}-21$ & 0.95 & 69 \\
\hline 6 & $\mathrm{FR} 2-16 \mathrm{M}+\mathrm{NaAlO}_{2}$ & 16 & 4.8 & SOD & 0.91 & 71 \\
\hline
\end{tabular}

${ }^{*}$ Molarity as calculated from the inserted $\mathrm{NaOH}+\mathrm{Na}_{2} \mathrm{O}$ content of the additive $\mathrm{NaAlO}_{2} ;{ }^{* *} \mathrm{INT}-1$ : intermediate zeolite with random disorder between sodalite and cancrinite [20] [21]; INT-2: intermediate zeolite with transition of stacking sequence to cancrinite [20] [21]; A: amorphous aluminosilicate; SOD: hydrosodalite [28] [29]; Z-21: zeolite Z-21 (PDF 27-1405 [17] [30]); ( ): low amounts.

Table 3. Main components of the reaction solutions of FR 1 and FR 2 from of direct one pot syntheses in dependence of the alkalinity at a temperature of $60^{\circ} \mathrm{C}$ and a duration of $4 \mathrm{~h}$.

\begin{tabular}{|c|c|c|c|c|c|c|c|c|c|c|c|}
\hline \multirow{2}{*}{$\begin{array}{l}\text { Exp. } \\
\text { No. }\end{array}$} & \multirow{2}{*}{$\begin{array}{c}\mathrm{NaOH} \\
(\mathrm{M})\end{array}$} & \multicolumn{10}{|c|}{ Chemical composition of reaction solution } \\
\hline & & $\begin{array}{l}\mathrm{SiO}_{2} \\
(\mathrm{~g} / \mathrm{l})\end{array}$ & $\begin{array}{c}\mathrm{Al}_{2} \mathrm{O}_{3} \\
(\mathrm{~g} / \mathrm{l})\end{array}$ & $\begin{array}{l}\mathrm{Fe}_{2} \mathrm{O}_{3} \\
(\mathrm{mg} / \mathrm{l})\end{array}$ & $\begin{array}{c}\mathrm{TiO}_{2} \\
(\mathrm{mg} / \mathrm{l})\end{array}$ & $\begin{array}{c}\mathrm{CaO} \\
(\mathrm{mg} / \mathrm{l})\end{array}$ & $\begin{array}{l}\mathrm{MgO} \\
(\mathrm{mg} / \mathrm{l})\end{array}$ & $\begin{array}{l}\mathrm{Na}_{2} \mathrm{O} \\
(\mathrm{g} / \mathrm{l}))\end{array}$ & $\begin{array}{l}\mathrm{K}_{2} \mathrm{O} \\
(\mathrm{g} / \mathrm{l})\end{array}$ & $\begin{array}{c}\mathrm{Cl}^{-} \\
(\mathrm{mg} / \mathrm{ml})\end{array}$ & $\begin{array}{c}\mathrm{SO}_{3} \\
(\mathrm{mg} / \mathrm{ml})\end{array}$ \\
\hline \multicolumn{12}{|c|}{ Alkaline solution of reaction of FR $1+\mathrm{NaAlO}_{2}$} \\
\hline 1 & 8 & 27.19 & 0.37 & 14.34 & 1.10 & 2.04 & 0.37 & 128.2 & 1.46 & 142.88 & 120.70 \\
\hline 2 & 12 & 34.18 & 0.88 & 34.46 & 0.80 & 2.42 & 0.78 & 202.45 & 1621.0 & 198.95 & 45.95 \\
\hline 3 & 16 & 38.01 & 1.91 & 94.39 & 12.57 & 0.08 & 3.34 & 256.70 & 1644.0 & 256.55 & 3.40 \\
\hline \multicolumn{12}{|c|}{ Alkaline solution of reaction of FR $2+\mathrm{NaAlO}_{2}$} \\
\hline 4 & 8 & 21.86 & 0.58 & 35.05 & 0.49 & 1.02 & 0.76 & 128.95 & 0.14 & 181.47 & 3.35 \\
\hline 5 & 12 & 28.01 & 1.57 & 85.12 & 1.33 & 1.86 & 0.84 & 205.30 & 224.2 & 192.36 & 1.40 \\
\hline 6 & 16 & 26.78 & 3.64 & 35.48 & 2.49 & 4.90 & 1.19 & 258.05 & 315.05 & 256.55 & 8.74 \\
\hline
\end{tabular}

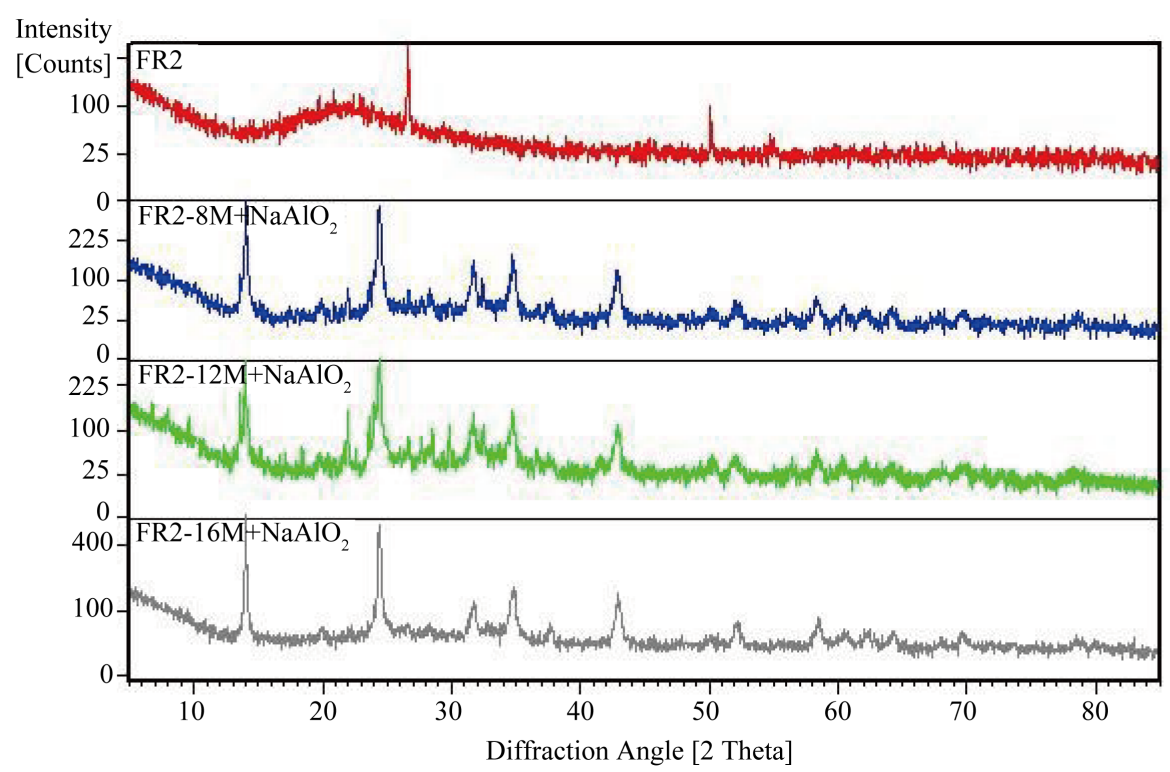

Figure 3. X-ray powder patterns of FR 2 and the products of FR $2+\mathrm{NaAlO}_{2}$ according to direct one pot synthesis at $60^{\circ} \mathrm{C}$ in dependence of the alkalinity. 
From Table 2 and Figure 1, Figure 2 it can be derived that the experiments with FR 1 and FR 2 yield to somewhat different reaction products under the applied low temperature $\left(60^{\circ} \mathrm{C}\right)$ conditions and $4 \mathrm{~h}$ duration. Only zeolite INT, a phase with intermediate structure between sodalite (SOD) and cancrinite (CAN) [20] [21] was obtained as crystalline reaction product from FR 1 beside amorphous aluminosilicate in $8 \mathrm{M} \mathrm{NaOH}$. The sodalite framework is formed by ABC stacking of layers of not directly connected $\left(\mathrm{AlSiO}_{4}\right)_{3}$ - rings along [111] as in cubic closest package. The cancrinite structure exhibits the AB stacking of the same layers parallel [0001] known from hexagonal closest package [22]-[27]. Random stacking between both sequences results in the structure of INT and as a consequence of this disorder the X-ray powder pattern of the intermediate phase shows only the reflections that sodalite and cancrinite have in common [20] [21] as can be seen in the patterns of Figure 1. At higher alkalinities (exp. No. 2 and 3, Table 2 and products obtained with $12 \mathrm{M}$ and $16 \mathrm{M} \mathrm{NaOH}$ in Figure 1) even zeolite INT was formed exclusively. But the evaluation of two further broad peaks at $19^{\circ} 2 \theta$ and $28^{\circ} 2 \theta$ in the pattern indicates slight transition from random disorder to more ordered structure and the product is thus termed INT-2 in Table 2. As both broad signals are the main lines of cancrinite, structure shows more and more features in direction of a (disordered) cancrinite. As carbonate anions have a strong structure directed effect on cancrinite formation the higher content of carbonate impurities of the super alkaline conditions of exp. No. 2 and 3 (Table 2) is responsible for this structural shift.

In contrast, sodalite is formed in each case the main phase under insertion of FR 2 . This phase was proved to be an expanded hydrosodalite $\mathrm{Na}_{6}\left[\mathrm{AlSiO}_{4}\right]_{6} \cdot\left(\mathrm{H}_{2} \mathrm{O}\right)_{4}(\mathrm{PDF}$ 42-216, [17] and [28] [29]). From Figure 4 formation of a minor second phase can be observed by insertion of FR 2. Here zeolite Z-21 (PDF 27-1405 [17] [30]) occurs during reaction of FR 2 under alkalinities of $8 \mathrm{M}$ and $12 \mathrm{M} \mathrm{NaOH}$ (see Figure 3 and exp. No. 4-5, Table 2) whereas pure phase hydrosodalite again exists under strongest alkaline conditions of $16 \mathrm{M} \mathrm{NaOH}$ as single phase (exp. No. 6, Table 1).

From the mass ratios, given in Table 2 no remarkable influence of the alkalinity on the course of the reactions can be derived. The values are similar to one and the same raw material but differif FR 1 or FR 2 is inserted. Whereas a lower range between 0.78 - 0.84 was observed by using FR 1 the interval $0.91-0.95$ could be found for FR 2. In comparison with FR 2, the lower ratios of the reaction products with FR 1 seem to be more a result of the different composition of the two filtration residues (see Table 1) than of remarkable differences in the course of the alkaline reactions. Thus, the higher silicate content of FR 2 mainly reflects these ratios. Most of this amount seems to be incorporated within the solid products whereas components like $\mathrm{MgO}$ and $\mathrm{SO}_{3}$ enriched in FR 1 will not enter the solid products if exclusively sodium aluminosilicate hydrates were formed during the reactions.

Beside this information from mass ratios, the distribution of $\mathrm{SiO}_{2}$ between the solid products and the solution gives some further information on the course of the reactions. Table 3 summarizes the data of chemical analysis of the reaction solutions from direct one pot syntheses experiments in dependence of the alkalinity. The insertion of $\mathrm{SiO}_{2}$ into the solid products (see Table 2) was calculated according to chemical analysis data of the solid FR 1 and FR 2 (free of loss of ignition, see Table 1) as well as the analyses of the solutions, summarized in Table 3. In general the incorporation of $\mathrm{SiO}_{2}$ into the solid phase is somewhat higher in the reactions with FR 2. Inde-

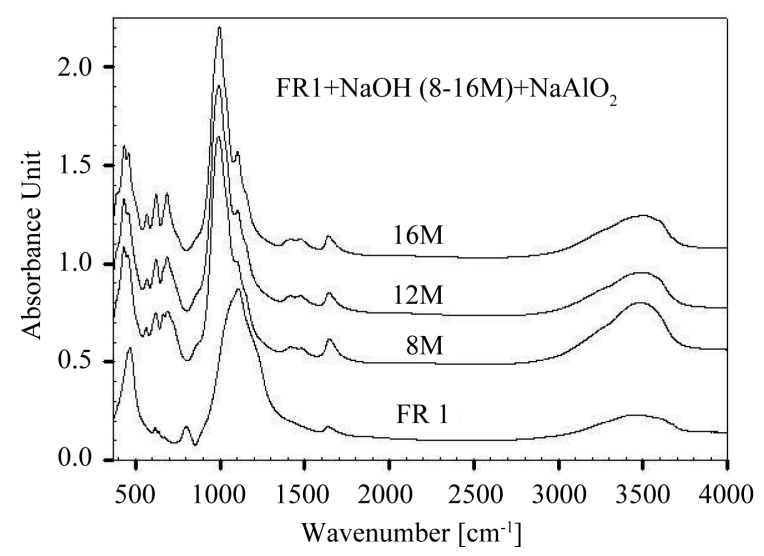

Figure 4. FTIR spectra of FR 1 and its products of direct one pot synthesis at $60^{\circ} \mathrm{C}$ in dependence of the alkalinity. 
pendent from the raw materials the highest conversion can be stated for reactions in $8 \mathrm{M} \mathrm{NaOH}$ for both (66\% for FR 1 and 76\% for FR 2 (see Table 2). About a third (FR 1) and a quarter (FR 2) of the silicate content will thus remain in the solutions under these conditions (see Table 3 ) and a re-use of the solutions should be tested in forthcoming experiments.

The FTIR spectra of reaction products of FR $1+\mathrm{NaAlO}_{2}$ in $8 \mathrm{M}, 12 \mathrm{M}$ and $16 \mathrm{M} \mathrm{NaOH}$ (No. 1-3, Table 2), recorded in the $400-4000 \mathrm{~cm}^{-1}$ range, are summarized in Figure 4. The spectrum of the raw material FR 1 is included in Figure 4 for comparison. As the main component of FR 1 is amorphous silica its spectrum exhibits weak resolved modes at wave-numbers $458 \mathrm{~cm}^{-1}, 506 \mathrm{~cm}^{-1}, 692 \mathrm{~cm}^{-1}, 778-797 \mathrm{~cm}^{-1}, 1078 \mathrm{~cm}^{-1}$ and $1164 \mathrm{~cm}^{-1}$ all around the region, known from quartz [31].

The FTIR spectrum " $8 \mathrm{M}$ " in Figure 4 (product, obtained in $8 \mathrm{M} \mathrm{NaOH}$ according exp. No. 1, Table 2) shows close resemblance with cancrinite (CAN) [18] [20] [21] [31] [32]. XRD revealed this product as intermediate phase between sodalite and cancrinite (INT). As in cancrinite, the intense broad asymmetric T-O-T $(\mathrm{T}=\mathrm{Si}$, Al) stretching mode at $\sim 1000 \mathrm{~cm}^{-1}$ and a sharp weaker one around $1100 \mathrm{~cm}^{-1}$ are well resolved. In the range of the symmetric T-O-T stretching vibrations and double ring modes of cancrinite $\left(755 \mathrm{~cm}^{-1}-567 \mathrm{~cm}^{-1}\right.$ according to Flanigen et al. [18]) the $755 \mathrm{~cm}^{-1}$ mode is absent in the spectrum of INT. Furthermore the bending modes at $460 \mathrm{~cm}^{-1}$ and $430 \mathrm{~cm}^{-1}$ were observed as in cancrinite, whereas the mode around $500 \mathrm{~cm}^{-1}$ is not resolved in the spectrum of INT but found in cancrinite [21] [32]. In addition a band at about $730 \mathrm{~cm}^{-1}$ can be observed in the spectrum of the intermediate phase not found in cancrinite but in sodalite [18], a hint of deviation in random stacking disorder in favour of the sodalite sequence [20] [21]. Thus, the deviation in the spectra of the intermediate phase and cancrinite are clearly reflecting the structural characteristics of both phases as result of the stacking disorder of INT, as mentioned above. The vibrations of the water molecules as well as of carbonate enclathrated within the cages of the intermediate phase, were also observed in the spectrum according to the characteristic IR active bands of water (bending mode at $1650 \mathrm{~cm}^{-1}$ and $\mathrm{O}-\mathrm{H}$ vibrations at $3100-3600 \mathrm{~cm}^{-1}$ ) and the asymmetric stretching mode of the carbonate group as doublet (1410 - $1450 \mathrm{~cm}^{-1}$ [19]).

The FTIR spectra "12 M" and "16 M" in Figure 4 of the products according exp. No. 2 and 3, Table 2, both exhibit very close resemblance with the spectrum of the $8 \mathrm{M}$ synthesis. In accordance with XRD, as also the intermediate zeolite between sodalite and cancrinite has been formed in both experiments. As a sign of a shift of stacking disorder in favour of cancrinte, the band at about $730 \mathrm{~cm}^{-1}$ (sodalite) is absent now and all bands are sharper, as can be seen at the asymmetric T-O-T stretching mode at $1100 \mathrm{~cm}^{-1}$ especially in the " $16 \mathrm{M}$ " product (see Figure 4).

The FTIR spectra of reaction products of FR $2+\mathrm{NaAlO}_{2}$ in $8 \mathrm{M}, 12 \mathrm{M}$ and $16 \mathrm{M} \mathrm{NaOH}$ (No. 4-6, Table 2) are summarized in Figure 5. The spectrum of the raw material FR 2 is included in this figure for comparison and has close resemblance with the spectrum of FR 1. As identified in FR 1, the bands of $\mathrm{SiO}_{2}$ can be seen again. Due to the amorphous character of FR 2, the bands are broad and not well resolved, especially the weaker quartz vibrations at $692 \mathrm{~cm}^{-1}, 778-797 \mathrm{~cm}^{-1}$ [31].

The FTIR spectrum of the product obtained in $8 \mathrm{M} \mathrm{NaOH}$ in Figure 5 (according exp. No. 4, Table 2) exhibits the vibrations of sodalite host framework in agreement with literature data [18] [31]. The strong asymmetric

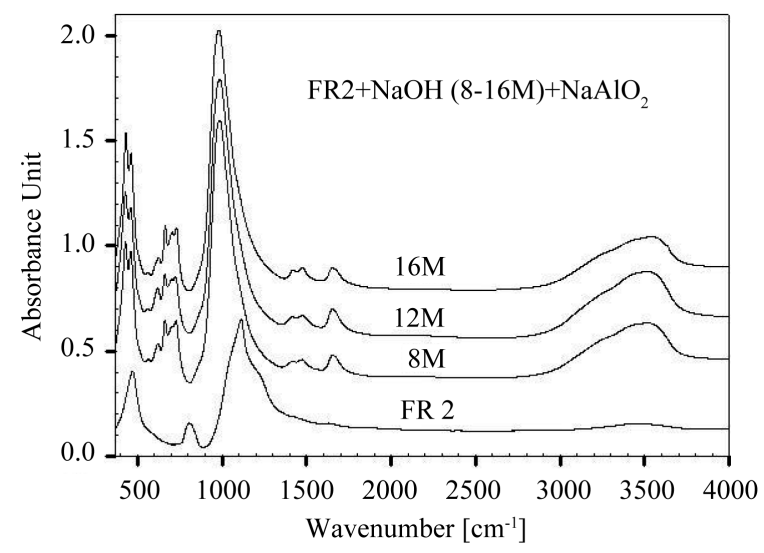

Figure 5. FTIR spectra of FR 2 and its products of direct one pot synthesis at $60^{\circ} \mathrm{C}$ in dependence of the alkalinity. 
$\mathrm{T}-\mathrm{O}-\mathrm{T}(\mathrm{T}=\mathrm{Si}, \mathrm{Al})$ stretching vibration at $1000 \mathrm{~cm}^{-1}$ and the weaker triplet of symmetric T-O-T vibrations in the $660 \mathrm{~cm}^{-1}-740 \mathrm{~cm}^{-1}$ beside the bending modes in the $400 \mathrm{~cm}^{-1}-500 \mathrm{~cm}^{-1}$ region are well resolved in this spectrum. The water molecules of the hydrosodalite (bending mode at $1650 \mathrm{~cm}^{-1}$; O-H-vibrations as broad band at $3100 \mathrm{~cm}^{-1}-3600 \mathrm{~cm}^{-1}$ and carbonate impurities at $1410 \mathrm{~cm}^{-1}$ and $1450 \mathrm{~cm}^{-1}$ [19]) can be clearly seen in the spectrum.

A further band at $630 \mathrm{~cm}^{-1}$ is caused by the amorphous aluminosilicate parts of the product according to $\mathrm{Al}-\mathrm{O}-\mathrm{Si}$ stretching vibrations as known from Al-Si-geopolymers [33]. Compared with products of FR 2, all products from FR 1 also contain amorphous parts but the $630 \mathrm{~cm}^{-1}$ vibration is overlapped here by strong absorption mode of the intermediate phase, formed with FR 1.

The FTIR spectra of the two products FR 2 " 12 M" and "16 M" in Figure 5 (according exp. No. 5 and 6, Table 2) show very close resemblance with the spectrum of the " $8 \mathrm{M}$ " product, as hydrosodalite was the main product in " $12 \mathrm{M}$ " synthesis and the single product under conditions of " $16 \mathrm{M}$ " $\mathrm{NaOH}$. The few amounts of zeolite Z 21 in the " 12 M" product cannot be distinguished by further bands in the FTIR spectrum, but differences in signal intensities and less pronounced signals in the region of aluminosilicate framework vibrations seem to be a result of the two phase mixture.

\subsection{Direct One Pot Synthesis at $60^{\circ} \mathrm{C}$ in Dependence of the Reaction Time}

The clarification that zeolites can successfully synthesized at low temperatures at $60^{\circ} \mathrm{C}$ under strong alkaline conditions was first given by Hadan and Fischer [14] and Fischer et al. [15] [16]. The authors used gels from pure chemicals. During their experimental study the important role of the reaction time under hyperalkaline condi- tions was further pointed out. If zeolites always crystallize under kinetic control, a time dependent crossover of zeolites Na-A and sodalite seems possible already in the period from 1 to $4 \mathrm{~h}$ duration [14].

In contrast to the results presented in literature, the experiments of direct one pot synthesis at $60^{\circ} \mathrm{C}$ are performed with waste materials FR 1 and FR 2 instead of pure chemical sodium silicate. Microporous zeolites INT or SOD are formed at a constant period of $4 \mathrm{~h}$ (see passage 3.1 above). Thus, testing the influence of the reaction time is now the second step of the experimental investigation. The early period of reactions at $1 \mathrm{~h}, 2 \mathrm{~h}$ and $3 \mathrm{~h}$ and synthesis at prolonged time $(12 \mathrm{~h})$ were therefore examined. As the experiments of one pot synthesis under variation of the alkalinity yield microporous zeolites already in $8 \mathrm{M} \mathrm{NaOH}$ and no other phases up to $16 \mathrm{M}$ $\mathrm{NaOH}$ (see former chapter) the time dependent reactions were performed in mother liquor equivalent to $8 \mathrm{M}$ $\mathrm{NaOH}$. To do not insert strong alkaline solutions, it is also meaningful for future applications in industrial waste recovery process from an economical point of view. Furthermore the production of high quantities of hyperalkaline waste solutions is prefented. The experimental conditions are given in Table 4.

The X-ray powder patterns of the products of time dependant reactions with FR 1 and FR 2 are summarized in Figure 6 and Figure 7. SEM images of these samples are shown in Figure 6. From XRD of the FR 1 series,

Table 4. Experimental conditions and syntheses products of direct one pot syntheses in dependence of the reaction time (temperature $60^{\circ} \mathrm{C}$ and $8 \mathrm{M} \mathrm{NaOH}$ for both series).

\begin{tabular}{|c|c|c|c|c|}
\hline No. & sample & Reaction time (h) & $\mathrm{NaAlO}_{2}(\mathrm{~g})$ & Products ${ }^{*}$ \\
\hline \multicolumn{5}{|c|}{ FR 1} \\
\hline 7 & $\mathrm{FR} 1-8 \mathrm{M}+\mathrm{NaAlO}_{2}-1 \mathrm{~h}$ & 1.0 & 3.2 & INT-1 + A \\
\hline 8 & $\mathrm{FR} 1-8 \mathrm{M}+\mathrm{NaAlO}_{2}-2 \mathrm{~h}$ & 2.0 & 3.2 & INT-1 + A \\
\hline 9 & FR1-8M+NaAlO $2-3 h$ & 3.0 & 3.2 & INT-1 + U+ A \\
\hline 10 & $\mathrm{FR} 1-8 \mathrm{M}+\mathrm{NaAlO}_{2}-12 \mathrm{~h}$ & 12.0 & 3.2 & INT-3 + (A) \\
\hline \multicolumn{5}{|c|}{ FR 2} \\
\hline 11 & $\mathrm{FR} 1-8 \mathrm{M}+\mathrm{NaAlO}_{2}-1 \mathrm{~h}$ & 1.0 & 4.8 & $\mathrm{NaA}+\mathrm{SOD}+\mathrm{A}$ \\
\hline 12 & $\mathrm{FR} 1-8 \mathrm{M}+\mathrm{NaAlO}_{2}-2 \mathrm{~h}$ & 2.0 & 4.8 & $\mathrm{SOD}+\mathrm{NaA}+\mathrm{A}$ \\
\hline 13 & $\mathrm{FR} 1-8 \mathrm{M}+\mathrm{NaAlO}_{2}-3 \mathrm{~h}$ & 3.0 & 4.8 & $\mathrm{SOD}+\mathrm{A}$ \\
\hline 14 & $\mathrm{FR} 1-8 \mathrm{M}+\mathrm{NaAlO}_{2}-12 \mathrm{~h}$ & 12.0 & 4.8 & $\mathrm{SOD}+(\mathrm{A})$ \\
\hline
\end{tabular}

*INT-1: intermediate zeolite with random disorder between sodalite and cancrinite [20] [21]; A: amorphous aluminosilicate; SOD: hydrosodalite [28] [29]; INT-3: intermediate zeolite with transition of stacking sequence to sodalite [20] [21] Z-21: zeolite Z-21 (PDF 27-1405 [17] [30]); U: unknown phase with some resemblance to sodium aluminum silicate hydrate PDF 43-577 [17]; ( ): low amounts. 


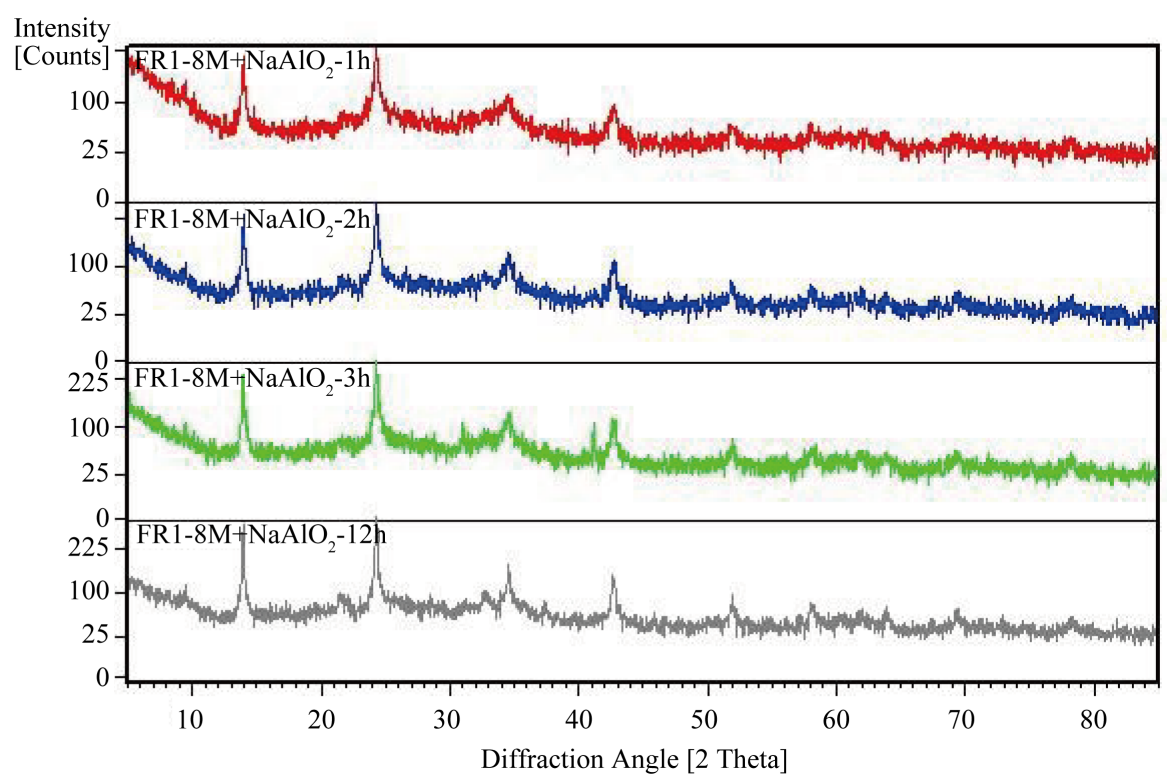

Figure 6. X-ray powder patterns of products obtained from FR $1+\mathrm{NaAlO}_{2}$ in direct one pot synthesis at $60^{\circ} \mathrm{C}$ in dependence of the reaction time.

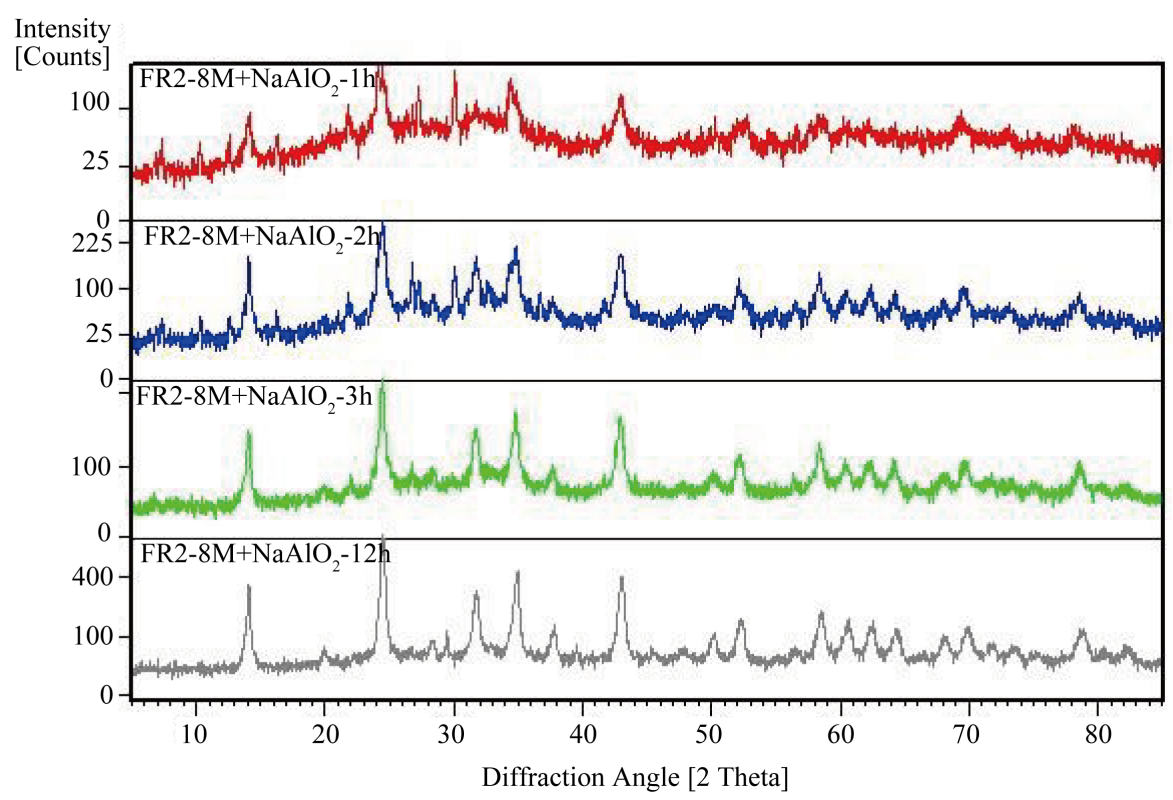

Figure 7. X-ray powder patterns of products obtained from FR $2+\mathrm{NaAlO}_{2}$ in direct one pot synthesis at $60^{\circ} \mathrm{C}$ in dependence of the reaction time.

formation of the intermediate zeolite between sodalite and cancrinite, termed INT-1 (Table 3) can be observed already after $1 \mathrm{~h}$ reaction time beside amorphous contributions with no changes even after 2 hours. Whereas the SEM image of untreated FR 1 raw material indicates very small nanoparticles (Figure 2(a)), the $1 \mathrm{~h}$ product contains the intermediate zeolite as spheroidal crystals of remarkable size between 0.5 - $0.8 \mu \mathrm{m}$ (see Figure 2(b)).

After the reaction period of three hours the same phase is obtained but it contains now surprisingly much smaller crystals (see Figure 6 and Figure 2(c)). Some new but weak reflections appear (for instance at $31^{\circ}$ and $41^{\circ} 2 \theta$ ) beside INT in the powder pattern of the $3 \mathrm{~h}$ product (Figure 2(c)). The new signals belong to a second phase (U, Table 4) that cannot definitely be identified due to the contribution of the strong pattern background. As this phase already disappears after $4 \mathrm{~h}$ (see Table 2 and Figure 1), its field of stability is located in a narrow 
window between $2 \mathrm{~h}-4 \mathrm{~h}$ reaction time.

In the $12 \mathrm{~h}$ product the intermediate zeolite between sodalite and cancrinite still exists as single phase. An appearance of a weak broad 530 reflex at $59^{\circ} 2 \theta$ and a 200 reflex at $20^{\circ} 2 \theta$ gives now a hint on the more sodalite like character of this phase termed INT-3 in Table 4 [20] [21]. This structural change can also be followed in Figure 2(d), where a shift from spherical to more polyhedral morphology can be seen.

The XRD patterns of the time dependant series with FR 2 are summarized in Figure 7. SEM images of selected products are given in Figures 2(e)-(h). A cocrystallization of remarkable amounts of zeolite NaA and hydrosodalite are found after $1 \mathrm{~h}$ reaction time. From the very fine grained FR 2 (see SEM picture Figure 2(e)) formation of big cube-like crystals of NaA beside spherulitic sodalites can be stated from the SEM photograph given in Figure 2(f). At prolonged times of $2 \mathrm{~h}$ and $3 \mathrm{~h}$ the amount of zeolite $\mathrm{NaA}$ is decreasing continuously (see Figure 7 and Figure 2(g)) and only a few cubes of zeolite A can be found during the SEM investigation (Figure 2(g)).

After 12 h hydrosodalite exists as single phase with high degree of crystallinity, as shown by the remarkable increase of intensities and the decrease of the background in the XRD pattern. Hydrosodalite crystals of around $1 \mu \mathrm{m}$ with spherical morphology were detected during SEM investigation within the 12 h product (see Figure 2(h)).

\subsection{Two Step Synthesis of Zeolites Na-A and Na-X from the Raw Materials FR 1 and FR 2}

In the one pot direct syntheses under hyperalkaline conditions at $60^{\circ} \mathrm{C}$ the technical important zeolites of high commercial interest like $\mathrm{NaA}$ could not be observed as pure phase by insertion of the filtration residues. Only a cocrystallisate of zeolite $\mathrm{NaA}$ and hydrosodalite could be synthesized from FR 2 as the only sample with some potential technical importance. The other products like pure hydrosodalite or the intermediate zeolite between sodalite and cancrinite have no technical application up to now. Nevertheless the direct syntheses experiments yield successful new information on the principle behaviour of the waste material FR under low temperature alkaline conditions and addition of $\mathrm{NaAlO}_{2}$.

With help of these findings on the digestion and crystallization behaviour of the FR-s under hyperalkaline low temperature conditions, a second synthesis pathway is now developed for transformation of FR 1 and 2 into zeolites NaA and $\mathrm{NaX}$. This reaction route, a "two step synthesis” first started with an alkaline leaching of FR in 8 $\mathrm{M} \mathrm{NaOH}$ at $60^{\circ} \mathrm{C}$ for $3 \mathrm{~h}$. After the alkaline slurry was diluted with water and mixed with $\mathrm{NaAlO}_{2}$ a gel crystallization was followed under usual conditions at 353 - $363 \mathrm{~K}$ for 3 - $16 \mathrm{~h}$ in Teflon coated steeI autoclaves. The amounts between $2 \mathrm{~g}$ and $0.5 \mathrm{~g} \mathrm{NaAlO}$ were inserted to test even formation of zeolite $\mathrm{NaX}$ in the silicate rich synthesis batch. The experimental conditions and syntheses products are summarized in Table 5 and the results of X-ray powder diffraction are summarized in Figure 8 and SEM photographs are shown in Figure 9. From Table 5 and the Figure 8, Figure 9 formation of pure phase zeolites NaA (No. 13, Table 5) and a co-crystallization of NaX and INT-1 (No. 14, Table 5) could be derived from these fine tuned syntheses conditions under insertion of FR 1. SEM analysis of the products of FR 1 show cubes of $1 \mu \mathrm{m}$ in size for zeolite NaA and intergrowths of NaX and INT-1 of sizes up to $1.5 \mu \mathrm{m}$ (see Figure 9, products FR 1-A and FR 1-X, photos on top).

Use of FR 2 yield to intergrowth of NaA cubes and octahedral crystals of NaX of size $<1 \mu \mathrm{m}$ in exp. No. 15 and pure phase zeolite $\mathrm{NaX}$ of octahedral shape and crystal size around $2 \mu \mathrm{m}$ in exp. No. 16, Table 4 (see Figure 9, products FR 2-A and FR 2-X, bottom photos).

The FTIR spectra of the zeolites NaA (FR 1-A and FR 2-A) and NaX (FR 1-X and FR 2-X), obtained from the two step syntheses according Table 5 are summarized in Figure 10. The spectra of commercial zeolites NaA (A-Std) and $\mathrm{NaX}$ (X-Std) are included in this figure as standard samples for comparison. The typical vibrations of zeolite A and X framework structures can be clearly seen for the pure phase products FR 1-A and FR 2-X in Figure 10, obtained in experiments No. 13 and 16, Table 5. The spectra are similar to the commercial zeolite standards and the literature data [18]. In agreement with XRD data, the two phase character of product No. 14 (zeolite Na A + INT-1) and No. 15 (mixture of Na A and some NaX) were observed even in the FTIR spectra of these samples. Thus, spectrum of product No. 14, INT-1 shows the double ring mode around $624 \mathrm{~cm}^{-1}$ and the symmetric T-O-T stretching mode at $680 \mathrm{~cm}^{-1}$. The other bands are overlapped by the strong vibration modes of the NaX-framework constituents. The small contribution of zeolite NaX in sample No. 15 (Figure 10 and Table 5) can be clearly observed according to the symmetric T-O-T stretching mode at $746 \mathrm{~cm}^{-1}$ in agreement with literature data [18]. 


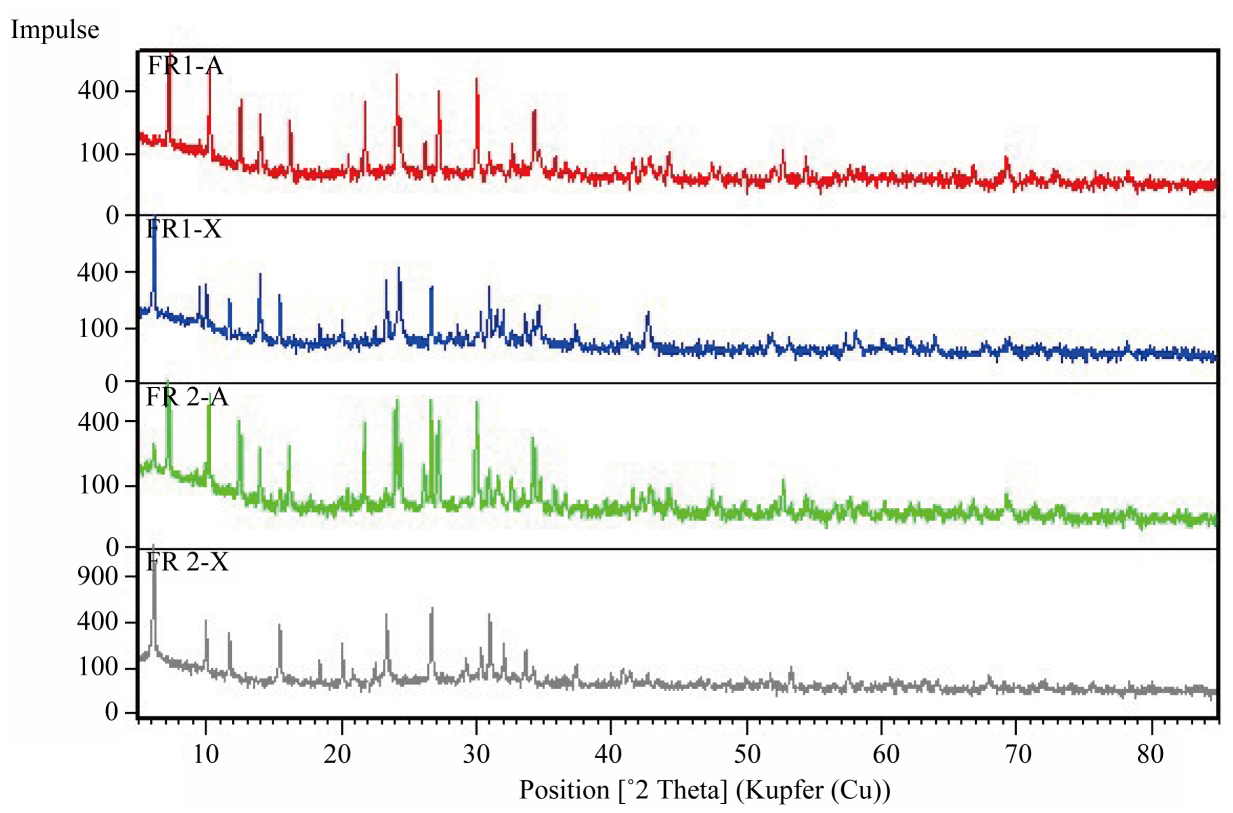

Figure 8. X-ray powder patterns of the products obtained by two step syntheses with FR 1 and FR 2.
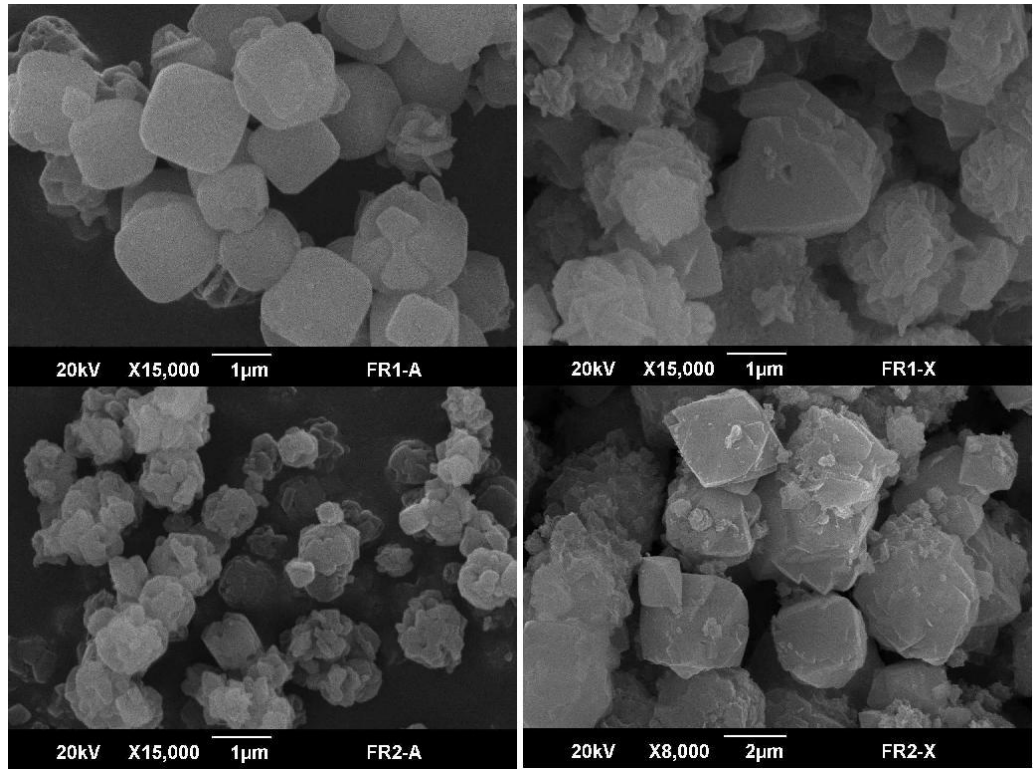

Figure 9. SEM- micrographs of the zeolites NaA (FR 1-A and FR 2-A) and NaX (FR 1-X and FR 2-X), obtained from the two step syntheses according Table 5.

The water molecules of the zeolites were observed in all spectra due to the bending mode of $\mathrm{H}_{2} \mathrm{O}$ at 1650 $\mathrm{cm}^{-1}$ and the broad band of O-H-vibrations between $3100 \mathrm{~cm}^{-1}-3600 \mathrm{~cm}^{-1}$. Some carbonate impurities were detected only in the product F R2-X according to the characteristic asymmetric stretching mode of the carbonate group in the $1410 \mathrm{~cm}^{-1}-1450 \mathrm{~cm}^{-1}$ [19]) region.

For a further characterization of the zeolite products, obtained from FR 1 and FR 2 by the two step synthesis route the BET- surface area and the water content was measured. The data are summarized in Table 6.

Sufficient physicochemical properties can be expected from these values for the products FR 1-A and FR 2-X as compared with literature data of commercial zeolites [2]. As the pore system of zeolite A is not accessible for nitrogen molecules due to the narrow $4 \AA$ opening windows of NaA structure, the low BET-value results for 
Table 5. Experimental conditions and syntheses products of the two step syntheses.

\begin{tabular}{|c|c|c|c|c|c|}
\hline No. & sample & Step No., solid educts and solvent & $\begin{array}{l}\text { Temp. } \\
\left({ }^{\circ} \mathrm{C}\right)\end{array}$ & $\begin{array}{l}\text { time } \\
(\mathrm{h})\end{array}$ & Products ${ }^{*}(\mathrm{Wt} \%)$ \\
\hline 13 & FR1-A & $\begin{array}{l}\text { 1. FR } 1(2 \mathrm{~g}), \mathrm{NaOH}(20 \mathrm{ml}, 8 \mathrm{M}) \\
\left.\text { 2. Slurry } 1+\mathrm{H}_{2} \mathrm{O}(30 \mathrm{ml})+\mathrm{NaAlO}_{2}(2 \mathrm{~g})\right)+20 \mathrm{ml} \mathrm{H} \mathrm{H}_{2} \mathrm{O}\end{array}$ & $\begin{array}{l}60 \\
80\end{array}$ & $\begin{array}{c}3 \\
22\end{array}$ & $\begin{array}{l}\text { Alkaline FR 1-slurry } \\
\text { NaA }\end{array}$ \\
\hline 14 & FR1-X & $\begin{array}{l}\text { 1. FR } 1(2 \mathrm{~g}), \mathrm{NaOH}(20 \mathrm{ml}, 8 \mathrm{M}) \\
\left.\text { 2. Slurry } 1+\mathrm{H}_{2} \mathrm{O}(30 \mathrm{ml})+\mathrm{NaAlO}_{2}(1.2 \mathrm{~g})\right)+20 \mathrm{ml} \mathrm{H}_{2} \mathrm{O}\end{array}$ & $\begin{array}{l}60 \\
90\end{array}$ & $\begin{array}{c}3 \\
16\end{array}$ & $\begin{array}{l}\text { Alkaline FR 1-slurry } \\
\mathrm{NaX}+\mathrm{INT}-1\end{array}$ \\
\hline 15 & FR2-A & $\begin{array}{l}\text { 1. FR } 2(2 \mathrm{~g}), \mathrm{NaOH}(20 \mathrm{ml}, 8 \mathrm{M}) \\
\text { 2. Slurry } 1+\mathrm{H}_{2} \mathrm{O}(20 \mathrm{ml})+\mathrm{NaAlO}_{2}(1.6 \mathrm{~g})+10 \mathrm{ml} \mathrm{H} \mathrm{H}_{2} \mathrm{O}\end{array}$ & $\begin{array}{l}60 \\
90\end{array}$ & $\begin{array}{c}3 \\
16\end{array}$ & $\begin{array}{l}\text { Alkaline FR 2-slurry LTA } \\
\mathrm{NaA}+\mathrm{NaX}\end{array}$ \\
\hline 16 & FR2-X & $\begin{array}{l}\text { 1. FR } 2(2 \mathrm{~g}), \mathrm{NaOH}(20 \mathrm{ml}, 8 \mathrm{M}) \\
\text { 2. Slurry } 1+\mathrm{H}_{2} \mathrm{O}(30 \mathrm{ml})+\mathrm{NaAlO}_{2}(0.5 \mathrm{~g})+20 \mathrm{ml} \mathrm{H}_{2} \mathrm{O}\end{array}$ & $\begin{array}{l}60 \\
80\end{array}$ & $\begin{array}{c}3 \\
22\end{array}$ & $\begin{array}{l}\text { Alkaline FR 2-slurry } \\
\mathrm{NaX}\end{array}$ \\
\hline
\end{tabular}

"INT-1: intermediate zeolite between sodalite and cancrinite; SOD: hydrosodalite; NaA: zeolite NaA; NaX: zeolite NaX.

Table 6. BET- surface area and water content of the zeolites NaA (FR1-A and FR 2-A) and NaX (FR 1-X and FR 2-X), obtained from two step syntheses according Table 5.

\begin{tabular}{ccccc}
\hline sample & $\begin{array}{c}\text { Exp. No. } \\
\text { (acc. Tab. 6) }\end{array}$ & $\begin{array}{c}\text { BET-surface area } \\
{\left[\mathrm{m}^{2} / \mathrm{g}\right]}\end{array}$ & $\begin{array}{c}\text { water content } \\
{[\%]}\end{array}$ & $\begin{array}{c}\mathrm{H}_{2} \mathrm{O}-\text { molecules } \\
\text { per formula unit }\end{array}$ \\
\hline FR1-A & 13 & $49.4(1)$ & 16.25 & 20 \\
FR1-X & 14 & $353.2(2)$ & 16.94 & 171 \\
FR2-A & 15 & $102.0(1)$ & 17.44 & 21 \\
FR2-X & 16 & $644.6(1)$ & 21.09 & 213 \\
\hline
\end{tabular}

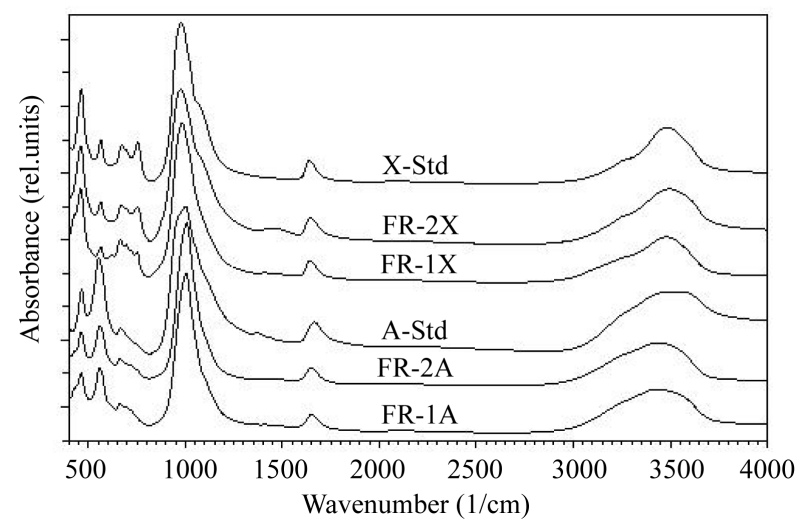

Figure 10. FTIR spectra of the zeolites NaA (FR 1-A and FR 2-A) and NaX (FR 1-X and FR 2-X), obtained from the two step syntheses according Table 5 . Spectra of commercial zeolites $\mathrm{NaA}(\mathrm{A}-\mathrm{Std})$ and $\mathrm{NaX}(\mathrm{X}-\mathrm{Std})$ are included as standard samples for comparison.

FR1-A. The slightly higher value of FR 2-A is caused by the small portions of zeolite X within the product (see Table 6). The deviation between the $\mathrm{X}$ zeolites has similar reasons: compared with FR 2-X the BET-surface area of FR 1-X is much to low, caused by the cocrystallization with zeolite INT-1 (see Table 6).

\section{Conclusions}

Principles of zeolite formation under use of filtration residues FR under strong alkaline conditions at low reaction temperatures could be shown from our experimental results. Compared with literature data of synthesis with gels obtained from pure chemicals, a remarkable shift of the onset of the zeolite NaA/hydrosodalite crossover reaction could be stated. Thus by the use of FR in direct one pot synthesis at $60^{\circ} \mathrm{C}$ a pure phase zeolite NaA was not observed in the $1 \mathrm{~h}-12 \mathrm{~h}$ interval. An alkalinity equivalent to insertion of $8 \mathrm{M} \mathrm{NaOH}$ was tested to be fully suitable for a rapid dissolution of FR and insertion of nucleation of zeolite phases already within the first hour of 
reaction.

The deviation in composition of the two filtration residues is expected to be responsible for the differences of the reaction under kinetic control and affects the structure type of the products. Either formation of zeolite INT with FR 1 (containing $80 \%$ by mass $\mathrm{SiO}_{2}$ ) or hydrosodalite with FR 2 (containing $93 \%$ by mass $\mathrm{SiO}_{2}$ ) were observed. Zeolite INT could be of interest in industry too, because the stacking disorder between the structures of sodalite and cancrinite will block the formation of a main structural channel. Cages of different size and length are the result. Thus, modified zeolitic behaviour of INT is expected.

Crystallization of pure phase NaA or NaX zeolites from both filtration residues is possible by alkaline low temperature digestion in $8 \mathrm{M} \mathrm{NaOH}$ for $3 \mathrm{~h}$ followed by a second crystallization step under addition of sodium aluminate and conditions of $80^{\circ} \mathrm{C}-90^{\circ} \mathrm{C}$ and times between $16-22 \mathrm{~h}$.

Further fine tuning of reaction conditions of one pot synthesis as well as possible re-use of the reaction solutions should be tested in forthcoming experiments.

\section{Acknowledgements}

We would like to thank the Deutsche Forschungsgemeinschaft for funding this research project.

\section{References}

[1] Barrer, R.M. (1978) Zeolites and Clay Minerals as Sorbents and Molecular Sieves. Academic Press, London.

[2] Breck, D.W. (1984) Zeolite Molecular Sieves: Structure, Chemistry and Use. John Wiley \& Sons Inc., New York.

[3] Barrer, R.M. (1982) Hydrothermal Chemistry of Zeolites. Academic Press, London.

[4] Aiello, R., Colella, C., Casey, D.G. and Sand, L.B. (1980) Experimental Zeolite Crystallization in Rhyolitic Ash-Sodium Salt Systems. Proceedings of 5th International Zeolite Conference, London, 1980, 49-55.

[5] Höller, H. and Wirsching, U. (1985) Zeolite Formation from Fly Ash. Fortschr. Miner, 63, 21-43.

[6] Grutzeck, M. and Siemer, D.D. (1997) Zeolites Synthesized from Class F Fly Ash and Sodium Aluminate Slurry. Journal of the American Ceramic Society, 80, 2449-2453. http://dx.doi.org/10.1111/j.1151-2916.1997.tb03143.x

[7] Maenami, H., Shin, H., Ishida, H. and Mitsuda, T. (2000) Hydrothermal Solidification of Wastes with Formation of Zeolites. Journal of Materials in Civil Engineering, 12, 302-306. http://dx.doi.org/10.1061/(ASCE)0899-1561(2000)12:4(302)

[8] Miyake, M., Tamura, C. and Matsuda, M. (2002) Resource Recovery of Waste Incinerator fly Ash: Synthesis of Zeolites A and P. Journal of Materials in Civil Engineering, 85, 1873-1875. http://dx.doi.org/10.1111/j.1151-2916.2002.tb00368.x

[9] Murayama, N., Yamamoto, H. and Shibata, J. (2002) Zeolite Synthesis from Coal Fly Ash by Hydrothermal Reaction Using Various Alkali Sources. Journal of Chemical Technology and Biotechnology, 77, 280-286. http://dx.doi.org/10.1002/jctb.604

[10] Anuwattana, R. and Khummongkol, P. (2009) Conventional Hydrothermal Synthesis of Na-A Zeolite from Cupola Slag and Aluminium Sludge. Journal of Hazardous Materials, 166, 227-232. http://dx.doi.org/10.1016/j.jhazmat.2008.11.020

[11] Di Renzo, F., Fajula, F., Figueras, F., Nicolas, S. and Des Courieres, T. (1989) Are the General Laws of Crystal Growth Applicable to Zeolite Synthesis? In: Jacobs, P.A. and van Santen, R.A., Eds., Zeolites: Facts, Figures, Future, Studies in Surface Science and Catalysis, Vol. 49, Part A, Elsevier, Amsterdam, 119-132.

[12] Daniels, R.H., Kerr, G.T. and Rollmann, L.D. (1978) Cationic Polymers as Templates in Zeolite Crystallization. Journal of the American Chemical Society, 100, 3097-3100. http://dx.doi.org/10.1021/ja00478a024

[13] Weigel, S.J., Gabriel, J.C., Puebla, E.G., Bravo, A.M., Henson, N.J., Bull, L.M. and Sheetham, A.K. (1996) StructureDirecting Effects in Zeolite Synthesis: A Single-Crystal X-ray Diffraction, Si-29 MAS NMR, and Computational Study of the Competitive Formation of Siliceous Ferrierite and Dodecasil-3C (ZSM-39). Journal of the American Chemical Society, 118, 2427-2435. http://dx.doi.org/10.1021/ja952418g

[14] Hadan, M. and Fischer, F. (1992) Synthesis of Fine Grained NaA-Type Zeolites from Superalkaline Solutions. Crystal Research and Technology, 27, 343-350. http://dx.doi.org/10.1002/crat.2170270310

[15] Fischer, F., Hadan, M. and Fiedrich, G. (1992) Zeolite Syntheses from Superalkaline Reaction Mixtures. Collection of Czechoslovak Chemical Communications, 57, 788-793. http://dx.doi.org/10.1135/cccc19920788

[16] Fischer, F., Hadan, M. and Horn, A. (1991) Investigations to the Synthesis of zeolite Na A for Using in Detergents from Superalkaline Solutions. Chem. Tech, 43, 191-195. 
[17] JCPDS (1997-2004) International Centre for Diffraction Data, 12 Campus Boulevard, Newton Square.

[18] Flanigen, Khatami, H. and Szymanski, H.A. (1971) Infrared Structural Studies of Zeolite Frameworks. Advances in Chemistry, 101, 201-228. http://dx.doi.org/10.1021/ba-1971-0101.ch016

[19] Weidlein, J., Müller, U. and Dehnicke, K (1981) Schwingungsfrequenzen. G. Thieme Verlag, Stuttgart.

[20] G. Hermeler, J.-Ch. Buhl and W. Hoffmann (1991) The Influence of Carbonate on the Synthesis of an Intermediate Phase between Sodalite and Cancrinite. Catalysis Today, 8, 415-426. http://dx.doi.org/10.1016/0920-5861(91)87020-N

[21] Grader, C. and Buhl, J.-C. (2013) The Intermediate Phase between Sodalite and Cancrinite: Synthesis of Nano-Crystals in the Presence of $\mathrm{Na}_{2} \mathrm{CO}_{3}$ /TEA and Its Thermal- and Hydrothermal Stability. Microporous and Mesoporous Materials, 171, 110-117. http://dx.doi.org/10.1016/j.micromeso.2012.12.023

[22] Gossner, B. and Mussgnug, F. (1930) Über Davyn und seine Beziehung zu Hauyn und Cancrinit. Zeitschrift für Kristallographie, 73, 52-60.

[23] Baerlocher, C., Meier, W.M. and Olson, D.H. (2001) Atlas of Zeolite Framework Types. 5th Edition, Elsevier, Amsterdam.

[24] Jarchow, O. (1962) Zur Struktur des Cancrinits. Fortschr. Mineralogie, 40, 55-56.

[25] Jarchow, O. (1965) Atomanordnung und Strukturverfeinerung von Cancrinit. Zeitschrift für Kristallographie, 122, 407-422. http://dx.doi.org/10.1524/zkri.1965.122.5-6.407

[26] Pauling, L. (1930) The Structure of Sodalite and Helvite. Zeitschrift für Kristallographie, 74, 213-225.

[27] Löns, J. and Schulz, H. (1967) Strukturverfeinerung von Sodalith $\mathrm{Na}_{8} \mathrm{Si}_{6} \mathrm{Al}_{6} \mathrm{O}_{24} \mathrm{Cl}_{2}$. Acta Crystallographica, 23, 434436. http://dx.doi.org/10.1107/S0365110X67002920

[28] Felsche, J. and Luger, S. (1987) Phases and Thermal-Decomposition Characteristics of Hydro-Sodalites $\mathrm{Na}_{8}\left[\mathrm{AlSiO}_{4}\right]_{6}(\mathrm{OH})_{\mathrm{x}} \cdot \mathrm{nH}_{2} \mathrm{O}$. Thermochimica Acta, 118, 35-55. http://dx.doi.org/10.1016/0040-6031(87)80069-2

[29] Engelhardt, G., Felsche, J. and Sieger, P. (1992) The Hydrosodalite System $\mathrm{Na}_{6+\mathrm{x}}\left[\mathrm{SiAlO}_{4}\right]_{6}(\mathrm{OH})_{\mathrm{x}} \cdot \mathrm{nH}_{2} \mathrm{O}$ Formation, Phase Composition and Dehydration and Rehydration Studied by 1H, 23N and 29Si MAS-NMR Spectroscopy in Tandem with Thermal Analysis X-Ray Diffraction and IR Spectroscopy. Journal of the American Chemical Society, 114, 1173-1182. http://dx.doi.org/10.1021/ja00030a008

[30] Barrer, R.M. and Beaumont, R. (1974) Characterization of the Synthetic Zeolite (Na, Me $\left.{ }_{4} \mathrm{~N}\right)-\mathrm{V}$. Journal of the Chemical Society, Dalton Transactions, 4, 405-407. http://dx.doi.org/10.1039/dt9740000405

[31] Moenke, H. (1966) Mineralspektren. Akademie Verlag, Berlin.

[32] Buhl, J.-C. (1991) Synthesis and Characterization of the Basic and Non-Basic Members of the Cancrinite-Natrodavyne Family. Thermochimica Acta, 178, 19-31. http://dx.doi.org/10.1016/0040-6031(91)80294-S

[33] Kriven, W.M., Bell, J.L., Gordon, M. and Wen, G. (2005) Geopolymers: More than Just Cements, Geopolymer, Green Chemistry and Sustainable Development Solutions. In: Davidovits, J., Ed., World Congress Geopolymer, 2005, The Geopolymer Institute, St. Quentin. 